\title{
Digitalization of Citizen Participation in Urban Development Management
}

\author{
Polina Krasilnikova ${ }^{1,2, *}$, and Svetlana Lapshina ${ }^{1,2}$ \\ ${ }^{1}$ Ural Federal University, 620002 Ekaterinburg, Russia \\ ${ }^{2}$ Ural State University of Economics, 620075 Ekaterinburg, Russia
}

\begin{abstract}
Currently, the process of digitalization of society has accelerated due to restrictions related to coronovirus. Nevertheless, the activity of citizens in solving issues related to the influence on decisionmaking on the development of territories is becoming more and more. New technologies are emerging that allow these manifestations of the active position of citizens. Information technology is increasingly entering our lives. The problem arises as the most effective use of digitalization processes for the development of regions and economic growth. Participation of the population in the development of strategic initiatives. The creation of the concept of "smart city," or "smart city," has become a necessary measure to solve a set of problems associated with an almost exhausted form of management of urban and municipal services, which today do not meet modern requirements for logistics, safety and ecology.
\end{abstract}

\section{Introduction}

Russian civil society is actively formulating a demand for effective democratic tools and methods of communication with the authorities. Thus, 2019 was rich in mass protests without a political agenda in the provincial regions: in Ingushetia there was a 30,000-yearold action against the change of administrative borders with Chechnya, in the Arkhangelsk region - for several months mass protests against the construction of a landfill at The Shies station, in Yekaterinburg - against the construction of a temple in the square.

In turn, the authorities perceive this signal and look for new mechanisms of communication. "Modern technologies, in the "digit" built, allow to respond quickly to the everyday problems of residents, to respond to their initiatives, appeals, to respond accordingly, and thus to solve more and faster problems that people face in everyday life," Vladimir Putin said at a meeting of the Council for the Development of Local Government.

The participation of the population in the management of the city and the right to control the activities of the authorities is the most important idea of local government, which, according to Article 130 of the Russian Constitution, "provides an independent solution of local issues to the population." In fact, the existing system of management of the socio-economic development of the city provides a very limited number of mechanisms of participation of the population.

${ }^{*}$ Corresponding author: ribnikoff@yandex.ru 
Forms of direct participation of the population in the implementation of local government are listed in the federal law on the general principles of local government organization in the Russian Federation: municipal elections, referendum, public hearings, public discussions, citizens' assembly, polls, appeals to the authorities and others.

In practice, municipal elections are the only form of direct democracy actually used by the population. In 2018, Levada Center conducted a study of civic activism, according to which $71 \%$ of Russians are ready to vote in the elections for parties or candidates offering a plan of change close to them, and the willingness to participate in various initiatives (elections, organizations, rallies, etc.) among active Internet users who go online daily or several times a week, higher than those surveyed who use the Internet rarely or do not go online.

\section{Methods and Types of the Earth's Remote Sensing}

The use of Internet technologies to increase the level of public involvement in the electoral process in Russia has been the subject of wide public discussion and expert environment in every electoral cycle since 2015. And despite the existing digital disparities among entities and types of settlements, according to Rosstat's statistical observation for $2019,79.9 \%$ of Russian households in cities have access to the Internet, and the share of the population who used the Internet to obtain public and municipal services was $77.6 \%$.

VTSIOM and the Center for Political Conditions in 2019 investigated the attitude of Russians to the technology of electronic voting and its prospects. The survey found that more than half of respondents approve of voting using Internet technologies: $71 \%$ in the 18 24 age group, and $51 \%$ in the $25-34$ age group.

The amendments approved in May 2020, allowing the introduction of electronic voting using Internet technologies in elections at all levels, have re-updated the discussion in the expert environment about the pros and cons of this form of voting.

Among the positive effects of the introduction of electronic elections can be identified the most significant: increased voter turnout through a more convenient remote service, the involvement of low-mobility categories of the population and citizens who live away from the place of permanent registration and for various reasons do not issue absentee certificates within the prescribed time, qualitative improvement of the processes of processing ballots and summing up. In addition, in the long term, the electronic format should reduce the overall cost of holding elections at all levels through the use of paperless voting and processing technologies, automation of counting and reduction of the number of premises and commission members involved in the constituency.

Opponents of electronic elections call the main argument "increased risks of failure, cyberattacks and manipulation". This is what happened at the polling stations, which in September 2019 as an experiment participated in the testing of electronic voting. According to the Information Technology Department of the Government of Moscow and the Central Electoral Commission, technical failures occurred, and representatives of the Communist Party and the non-systemic opposition claimed that the elections were rigged and the pressure on voters was canceled and demanded the cancellation of the results of the vote in court.

In the world practice, the main problems of electronic voting also remain unresolved: technical difficulties, ethical issues and the complexity-of shaping the valueof"electronic"voices.

The concept of electronic communications between the population and the authorities is not new and has been actively implemented in Russia since 2009 through the following programs, projects and services: the Information Society program, the Electronic Government Project, the Single Portal of State and Municipal Services, the United 
Interagency Electronic Interaction System, the State Information System of Housing and Utilities. The existence of a digital platform to involve citizens in urban development is a basic requirement in the standard "Smart City" presented by the Ministry of Construction in 2019.

The Earth's remote sensing (ERS) is the process of data collection about the Earth's surface without direct contact with it. The ERS is performed using unmanned aircraft systems (UASs), aviation assets and aerospace systems (aircrafts, helicopters, space ships, satellites, etc.), ships and submarines, and earth-based stations.

The remote sensing is based on the principle of using electromagnetic radiation as a carrier signal that is reflected from the object (or emitted by the object), returned back and recorded at some space point by the receiver, and then, is interpreted in one way or another. The ERS methods can be either active (laser, radar, etc.) or passive (reflected solar energy, intrinsic electromagnetic radiation of the Earth's surface, etc.).

Since the main specifications of electromagnetic radiation include the wavelength $\lambda$ and frequency $v$, all ERS types can be divided into groups depending on the electromagnetic spectrum interval (from $0.25 \mu \mathrm{m}$ to $1 \mathrm{~m}$ ) [12]. The surveys are performed in the ultraviolet (UV), visible, near infrared (IR), middle IR, thermal IR and radio-wave bands. In this case, the atmosphere (molecules of oxygen, ozone, carbon dioxide, water vapor) absorbs the radiation of one or another electromagnetic spectrum range in different ways. When using the ERS data of different spectra, it is also necessary to remember the different spectral reflectivity of the vegetation cover, soils and denudations, water surfaces and snow deposits that requires appropriate skills of the performer.

The ERS results include a two-dimensional metric image of specific areas and objects in the form of a photograph. Depending on the type of the wave signal receiver and emitter, the value of the reflected signal in the image can be expressed, for example, by the color saturation of the resolution cell. Based on such images, it becomes possible to study the features of landscapes and topographical forms from the local to global scales, the hydrosphere, biosphere, and lithosphere of the earth.

It is worth noting that in recent decades, the share of the Earth space survey materials has significantly prevailed over the aerial photographic materials due to the economic costs, greater spatial reach and the imaging technology development. The Earth's remote sensing has contributed to the emergence of new research areas, such as the satellite meteorology, satellite hydrophysics, space oceanology, space mapping, space geodesy, etc. In this case, the ERS use for daily geo-ecological monitoring holds a specific place.

The remote sensing data in hydrology is used for interpretation of the linear and areal water bodies, catchment area identification, estimation of evaporation from the earth's surface and amount of precipitations, monitoring of the high waters and floods, hydrological process modeling, including for observation of the snow melting processes in order to predict the runoff volume [12].

For the drainage basins, the main component that determines its configuration is the terrain. The Earth surface relief data can be represented in the form of a digital elevation model (DEM). Based on the DEM, it is possible to obtain the drainage lines, water course length, position of watersheds, slope angles, etc. The specifications and properties of the hydrological model directly depend on the quality of terrain models; therefore, it becomes extremely important to select the optimal source of the ERS data for subsequent use [6].

\section{Analysis of the Main ERS Data Sources for the DEM Development}

We propose to consider the need and possibility of introducing electronic technologies in terms of citizens' participation in the management of the territorial development of the city 
on the example of Yekaterinburg, one of the largest cities participating in the pilot program of the Russian Ministry of Construction "Smart City."

Ekaterinburg's strategic plan defines the goal as "developing a community of free, proactive, socially active citizens", "improving the efficiency of local government and improving the system of partnership between the institutions of power and the local community." The share of the population involved in the implementation of local government for 2017 is $41 \%$, the stated target for 2035 is $58 \%$. Its achievement is possible only by expanding and qualitatively improving the available forms of participation: the administration needs to shift the focus from turnout to municipal elections and increase the importance of other activities, such as public surveys, public hearings and discussions. The events of 2019 around the construction of the temple allowed to see the potential of the above forms.

From December 21, 2018 to January 18, 2019, the city administration conducted an electronic survey on the official city portal on the construction of the temple. According to the mayor's office, out of 3,309 citizens who took part in the voting, 3,107 supported the project. The mayor's office concludes that in this way the participants were in favor of the construction of the temple.

However, after the installation of the fence at the site of the construction of the facility began mass protests, which lasted for 8 days and attracted the attention of the federal media and comments from the Kremlin. On May 16, the President called for a poll of local residents. The city administration decided to conduct a citywide poll of residents in the traditional form for elections: with ballots and polling stations. The survey cost the city 6 million rubles, 1 million of which was spent on the production of ballots. The poll was conducted on October 13, with a turnout of 97,143 people.

The development of the situation revealed problems with the representativeness of the data obtained by the city administration through surveys on its portal. First, there was a lack of awareness of the fact of the survey. The average attendance of the official website of the city administration according to the metric is 56,210. For comparison, the average attendance of the network edition "E1.RU Yekaterinburg Online", the participants of the survey on this site took - 23,334. Second, the organization of the survey: the Google forms used are associated, more, by discussion on the local Internet forum, rather than by voting influence on a socially significant issue. In addition, google form does not involve identifying the user and protecting against unfair activity. The rating vote on the selection of public areas to be landscaping as a matter of priority in 2021 under the "Formation of a Modern Urban Environment" program was conducted in a similar way. In the near future, the administration of Yekaterinburg will have to return to the population survey in one form or another to carry out transport reform. As practice has shown, previous reform projects prepared for 8 and 9.3 million rubles did not take into account the opinion of the population and led to social tension.

With a total population of $1,526,384$ in the municipal education population, the main target audience for electronic voting is citizens between 18 and 35 years old, with an estimated population of 335,000 (if you extrapolate data on the age structure of the urban population of the Sverdlovsk region to Yekaterinburg).

\section{Conclusions}

In order to improve the quality of such online surveys, it is necessary to consider the possibility of introducing mandatory authorization, because according to the researchers (with whom the authors of the article are in solidarity) in the conditions of anonymity of Internet voting objectively reduces the level of responsibility. 
To ensure that the polling and public discussion page is quickly navigated by directly moving from the homepage: for example, add an "electronic poll" field in the residents tab;

- Change access settings: when you go to the survey block in the active user window, you should see a pop-up window of entry through the government portal (currently, authorization is required to participate in the survey, and access to the site is only possible from the home page);

- to oblige the administration of the site not to collect personal data of the authorized user, the user is informed about it before each survey;

In order to reduce reputational risks and replace the Institute of Public Observers, install a public widget to monitor user activity throughout the current survey;

Offer the user the opportunity to receive notification of public hearings in the area of residence;

- Add the option of subscribing to surveys on thematic and territorial blocks to the email address and a widget "share on social networks" to popularize and expand coverage.

Discussion. Thus, on the one hand, the residents of the city, actively expressing indignation about the transport reform and the construction of the temple, clearly articulated the desire to participate in the management of the city.

Already, we can talk about the digitization of citizens' participation in local government by remote electronic voting and participation in the management of territorial development within the competences of municipalities. First of all, we are talking about participation in elections, polls and public debates. The use of information technology solves the problem of prompt expression of citizens' will, reduces the cost of democratic procedures for the city administration, and in the long run contributes to the increase in the participation of citizens from the 18-35 age group.

\section{References}

1. Digitalization and communication: how will the communication between Russians and the authorities change, Russia Today, 31 Jan (2020), https://ria.ru/

2. The Constitution of the Russian Federation of 12.12 .1993 (taking into account the amendments made by the Russian Constitution Amendments to the Constitution of 30.12.2008 N 6-FKS, From 30.12.2008 N 7-FKS, from 05.02.2014 N 2-FKS, from 21.07.2014 N 11-FKS), http://www.consultant.ru/

3. Federal Law of 06.10.2003 N 131-Fz (ed. 23.05.2020) "On the general principles of local government organization in the Russian Federation"

4. Civic Activity: Press Release of Sociological Research, Levada Center (2019) https://www.levada.en/

5. D.E. Dobrinskaya, T.S. Martynenko, Herald of the RUDN Series: Sociology, 1 (2019)

6. Selective federal statistical observation on the use of information technology and information and telecommunications networks by the population, Federal Office for State Statistics (2019) https://gks.ru/

7. Analytical report "Electronic Voting: New Technologies Are Changing Electoral Habits", VTSIOM, Center for Political Conditions, https://wciom.ru/

8. Federal Law of May 23, 2020 No. 154-Fz "On amending certain laws of the Russian Federation", http://publication.pravo.gov.ru/

9. V.I. Podgorny, E.S. Lysenko, UIA Herald, 1(87) (2020) https://cyberleninka.ru/ 
10. Decision in case No. 2a-296/2019, Chertanovsky District Court in Moscow, 30 Oct (2019) https://www.mos-gorsud.ru/

11. F. T. Fornoni, Why e-democracy is not a possible reality (yet) a literature review on the challenges to the applicability of e-democracy (2019)

12. Order of the Russian Ministry of Construction of April 24, 2019 No. 235/p. "On the approval of methodical recommendations for the inclusion of measures on the digitization of urban economy in the state programs of the subjects of the Russian Federation and municipal programs for the formation of a modern urban environment as part of the implementation of the federal project "Formation of a comfortable urban environment", https://www.minstroyrf.ru/

13. Strategic Plan for the Development of the City of Yekaterinburg until 2030: Approved by the Decision of the Ekaterinburg City Duma of May 25, 2018 No. 12/81 "On amending the Decision of the Ekaterinburg City Duma of June 10, 2003 No. 40/6 "On the Strategic Plan for The Development of Yekaterinburg", ekaterinburg.rf

14. More than 700,000 ballots will be produced for the Yekaterinburg Temple Survey,TIAS: State News Agency, 21 Sep.(2019) https://tass.ru/

15. A. Vysokinsky, "Together we have written a new page of history", the official portal of the administration of Yekaterinburg, 14 Oct. (2019) ekaterinburg.rf

16. The number and age-sex composition of the population of Sverdlovsk region: database, Office of the Federal State Statistics Service for Sverdlovsk and Kurgan region, http://sverdl.old.gks.en/

17. S.M. Popova, On the need to take into account the effects of digital inequality to assess the quality of Internet democracy in Russia, https://nbpublish. com/ 